\title{
Age and multiple mating effects on reproductive success of Grapholita molesta (Busck) (Lepidoptera, Tortricidae)
}

\author{
Rosana M. de Morais ${ }^{1}$, Luiza R. Redaelli ${ }^{1} \&$ Josué Sant’Ana ${ }^{1}$
} ${ }^{1}$ Programa de Pós-Graduação em Fitotecnia, Departamento de Fitossanidade, Faculdade de Agronomia, Universidade Federal do Rio Grande do Sul,
91540-000 Porto Alegre-RS, Brasil. entomorais@yahoo.com.br

\begin{abstract}
Age and multiple mating effects on reproductive success of Grapholita molesta (Busck) (Lepidoptera, Tortricidae). The reproductive success of the oriental peach moth was evaluated in four experiments: 1) assessment of the mating duration, fecundity, fertility and longevity of females paired with virgin and immediately mated males; 2) mating duration, spermatophore size, fecundity, fertility and longevity in females paired with virgin and up to four times mated males; 3 ) receptivity of females to additional copulations after mating with virgin or mated males, and the effects of this behavior in female fecundity, fertility and longevity; 4) influence of insects age in the reproductive output. Males (33\%) could copulate immediately after a previous copula. They were fertile until the fourth mating, but only in the first copula they transferred the longest $(1.43 \pm 0.10 \mathrm{~mm})$ and widest $(0.83$ $\pm 0.11 \mathrm{~mm})$ spermatophore, presenting the fastest mating duration $(34.8 \pm 2.62 \mathrm{~min})$. A high proportion of females copulated by non-virgin males (84\%) was receptive to other copulas, in comparison to those copulated by virgin males (32.4\%). However, the fecundity, fertility, and longevity were similar among females that copulate once or more. The age was the most important factor affecting reproductive variables, where one and three day old insects had a significant higher fecundity, fertility and presented a shorter mating duration in comparison with older individuals. Results pointed out that the reproductive capacity of Grapholita molesta changes a little with respect to the analyzed factors, highlighting the elevated biotic potential of the species.
\end{abstract}

KEYWORDS. Age; copulations; fertility; oriental fruit moth.

RESUMO. Efeito da idade e de múltiplos acasalamentos no sucesso reprodutivo de Grapholita molesta (Busck) (Lepidoptera, Tortricidae). O sucesso reprodutivo da mariposa-oriental foi avaliado em quatro bioensaios: 1) avaliação do tempo de cópula, fecundidade, fertilidade e longevidade de fêmeas pareadas com machos virgens e imediatamente acasalados; 2) tempo de cópula, tamanho do espermatóforo, fecundidade, fertilidade e longevidade em fêmeas pareadas com machos virgens e acasalados até quatro vezes; 3 ) receptividade de fêmeas a cópulas adicionais após o acasalamento com machos virgens ou acasalados, e o efeito deste comportamento na fecundidade, fertilidade e longevidade das fêmeas; 4) influência da idade dos insetos no sucesso reprodutivo. Machos (33\%) foram capazes de copular logo após o primeiro acasalamento. Os machos foram igualmente férteis até o quarto acasalamento, mas somente na primeira cópula transferiram espermatóforo com maior comprimento $(1,43 \pm 0,10 \mathrm{~mm})$ e na largura $(0,83 \pm 0,11 \mathrm{~mm})$, e apresentaram cópula de menor duração $(34,8 \pm 2,62 \mathrm{~min})$. Uma maior proporção de fêmeas copuladas por machos não virgens ( $84 \%$ ) foram receptivas a novos acasalamentos em comparação as pareadas com virgens (32,4\%). No entanto, a fecundidade, fertilidade e longevidade foram semelhantes entre as fêmeas que copularam uma ou várias vezes. A idade foi o fator que mais afetou as variáveis reprodutivas, onde insetos de um e três dias de idade foram significativamente mais fecundos, férteis e apresentaram menor tempo de cópula que os mais velhos. Os resultados apontam que a capacidade de reprodução de $G$. molesta altera-se pouco com relação aos fatores analisados, ressaltando assim, elevado potencial biótico da espécie.

PALAVRAS-CHAVE. Idade; cópulas; fertilidade; mariposa-oriental.

In despite of costs that multiple copulations may raise, the use of such behavior also incurs in advantages for several lepidopterans species (Torres-Vila et al. 2004; Torres-Vila \& Jennions 2005). Males would be favored in transferring sperm to a higher number of partners (Wiklund 2003), and females, by the acquisition of genetic diversity, possibility of sperm selection, and nutritional benefits (Wedell 2003), which may increase fecundity, reproductive period and lifespan (Svärd \& McNeil 1994; Wedell et al. 2002).

The increase in oviposition rate as a function of matings may be caused by stimuli originated from several factors, such as spermatophore presence in the bursa copulatrix, fluids in the seminal receptacle, and spermatic cells in the spermatheca, as registered in Zeiraphera diniana (Guenée, 1845) (Tortricidae) (Benz 1969). In Bombyx mori (Linnaeus, 1785)
(Bombycidae), only the presence of fertile spermatic cells, which stimulate the abdominal ganglia placed in the seminal duct junction, were responsible for an increase in the number of eggs (Karube \& Kobayashi 1999).

The substances transferred by the males may also modify the female reproductive behavior (Gillot 2003). Secretions from male accessory glands and apyrene cells may determine the female refractory period, by decreasing or even stopping the pheromone release (Kingan et al. 1993). In Epiphyas postvittana (Walker, 1863) (Tortricidae), mating triggers a permanent inactivation of pheromone production in the female (Foster 1993), which is not originated by the spermatophore mechanic pressure in the bursa copulatrix. Hormonal and neural factors were the most relevant to explain such phenomena. 
The spermatophore size may vary depending on the number of male's previous matings (Jiménez-Pérez \& Wang 2004; Marcotte et al. 2005; Knight 2007). Although the male reproductive success is related to the number of females they can copulate with, multiple matings in Spodoptera littoralis (Boisduval, 1833) (Noctuidae) resulted in spermatophores with reduced fertilization ability and induction of a brief refractory period (Sadek 2001).

The age, which the mating occurs, affects the reproductive performance. Average fecundity and fertility of one day old females of Lobesia botrana (Denis \& Schiffermueller, 1776) (Tortricidae) were 150 eggs and 90\%, respectively. However, 16 days old mated females deposited 22 eggs during the same period, which $23 \%$ were fertile (Torres-Vila et al. 2002). Similar results were observed in other Tortricidae species such as $E$. postvittana (Foster \& Howard 1999) and Argyrotaenia sphaleropa (Meyrick, 1909) (Pinto et al. 2005). The fertilization capacity depends on the males age. Average fecundity and fertility of Cydia pomonella (Linnaeus, 1758) females paired with one and seven days old males reduced, compared with those mated with two and three days old ones (Knight 2007).

The oriental fruit moth, Grapholita molesta (Busck, 1916) (Tortricidae) is a polygamous species, and important pest of peaches and apples (Salles 2001). The mechanisms involved in mating and its effects on the species biotic potential are important for the improvement of control strategies. This study aimed to evaluate the effects of age and multiple copulations in the reproductive success of G. molesta.

\section{MATERIAL AND METHODS}

Adults of $G$. molesta came from a culture kept under controlled conditions (photoperiod of 16 hours; $25 \pm 1{ }^{\circ} \mathrm{C} ; 60 \pm$ $5 \%$ R.H.), at the Department of Fitossanidade, Universidade Federal do Rio Grande do Sul, southern Brazil. Adults were reared with honey solution (15\% honey and 5\% Nipagin) and the larvae on artificial diet (Arioli et al. 2007).

Three-day-old virgin insects were paired and placed in $250 \mathrm{~mL}$ plastic cylinders, and continuously observed for three hours and half before scotophase, recording the occurrence and duration of copulation. Statistical analyses were performed using the Bioestat 4.0 software (Ayres et al. 2005). Four experiments were conducted, as described below.

Assessment of the mating duration, fecundity, fertility and longevity of $G$. molesta females paired with virgin and immediately mated males. Just after the first copulation, males were immediately paired with another virgin female. After each pairing, the copulated females were individually isolated in $500 \mathrm{~mL}$ plastic cylinders with food. The number of eggs were recorded daily until the female death. Fecundity, fertility, longevity and mating duration of 38 females were evaluated, 19 mated with virgin males and the remaining ones with mated males. The treatments were compared by Mann-Whitney test $(\alpha=0.05)$.

Evaluation of the mating duration, spermatophore size, fecundity, fertility and longevity in females paired with virgin and until four times mated males. The reproductive success of once $(n=45)$, twice $(n=38)$, three $(n=$ $29)$ and four $(n=23)$ times-copulated males was evaluated daily through the fecundity and fertility of three-days-old virgin females. The copulated females were isolated in plastic cylinders $(500 \mathrm{~mL})$ containing food, and their postures were followed during 15 days. Another group of females, under the same conditions previously described, paired with males at their first $(n=37)$, second $(n=26)$, third $(n=18)$ and fourth $(n=15)$ copulation, were dissected right after the mating, and the spermatophore length and width were measured. The means were compared by the Kruskal-Wallis test $(\alpha=0.05)$ for all the variables. The correlation between the spermatophore size and the number of males copulations was tested by using the Pearson Correlation and Simple Linear Regression.

Assessment of the receptivity of $G$. molesta females to recopulation after mating with virgin or mated males, and its effects in fecundity, fertility and longevity. Two groups of females were compared, one with three-day-old virgin females $(n=34)$ mated with virgin males of the same age, and other with virgin females $(n=25)$ paired with once mated males 24 hours before. After the first mating, all females started to receive a three-days-old virgin male daily, remaining with it for three hours and half. The proportion of copulation between the two groups of females was compared using the heterogeneity Chi-Square test. Regarding to the females paired only with virgin males, the fecundity, fertility and longevity of the females that copulated once were compared to those ones that copulated twice or more times. The means were compared by the Mann-Whitney test $(\alpha=0.05)$.

Influence of insect age in the reproductive output. Virgin adults of both sexes were paired when they were one $(\mathrm{n}=$ $35)$, three $(n=30)$, six $(n=62)$, nine $(n=27)$ and $12(n=41)$ days old. After the pairing period, each female that had copulated was isolated in a plastic cylinders $(500 \mathrm{~mL})$ containing food, the postures were counted, and the egg fertility was daily recorded for ten days.

The average fecundity, fertility and mating duration were compared among the treatments by using Kruskal-Wallis test $(\alpha=0.05)$. The correlation among the variables was assessed through Pearson Correlation and the Simple Linear Regression.

\section{RESULTS}

The mating duration, fecundity, fertility and longevity of females paired with virgin and immediately mated males. Among the mated males, 33.3\% recopulated. The second pairing took 32 minutes, on average, after the first one. The first mating duration was from 28 to 47 minutes, and the second from 122 to 1.110 minutes, being both significantly different $(\mathrm{U}=0 ; \mathrm{df}=1 ; \mathrm{P}<0.0001)$. The mating time did not affect fecundity $(\mathrm{U}=122.5 ; \mathrm{P}=0.141)$, fertility $(\mathrm{U}=125$; $\mathrm{df}=1 ; \mathrm{P}=0.162)$, and longevity $(\mathrm{U}=137 ; \mathrm{df}=1 ; \mathrm{P}=0.204)$ (Table I). 
Table I. Fecundity, fertility, longevity (days) and mating duration (min) means $( \pm$ SE) of females paired with Grapholita molesta virgin $(\mathrm{n}=19)$ and mated males $(\mathrm{n}=19)$.

\begin{tabular}{ccccc}
\hline & Fecundity & Fertility & Longevity & Mating duration \\
\hline Virgin & $115.4 \pm 11.38 \mathrm{a}^{*}$ & $102.6 \pm 11.58 \mathrm{a}$ & $13.9 \pm 1.07 \mathrm{a}$ & $35.7 \pm 1.25 \mathrm{~b}$ \\
Mated & $92.7 \pm 16.36 \mathrm{a}$ & $78.0 \pm 17.41 \mathrm{a}$ & $15.4 \pm 0.70 \mathrm{a}$ & $527.8 \pm 50.29 \mathrm{a}$
\end{tabular}

* Means values followed by distinct letters in the column differ significantly $(\alpha=0.05)$.

The mating duration, spermatophore size, fecundity, fertility and longevity in females paired with virgin and until four times mated males. The first mating average duration (min) was significantly shorter than the others $(\mathrm{H}=7.43 ; \mathrm{df}=3 ; \mathrm{P}<0.05)$ (Table II). The fecundity $(\mathrm{H}=2.787 ; \mathrm{df}=3 ; \mathrm{P}=0.425)$, fertility $(\mathrm{H}=2.361 ; \mathrm{df}=3$; $\mathrm{P}=0.501)$ and longevity $(\mathrm{H}=1.795 ; \mathrm{df}=3 ; \mathrm{P}=0.616)$ was not significantly affected by the number of the males copulation (Table II). The spermatophore from the first copulation was significantly larger in length $(1.43 \pm 0.10 \mathrm{~mm})$ $(\mathrm{H}=71.93 ; \mathrm{df}=3 ; \mathrm{P}<0.05)$ and width $(0.83 \pm 0.11 \mathrm{~mm})$ $(\mathrm{H}=55.55 ; \mathrm{df}=3 ; \mathrm{P}<0.05)$ (Table III). The spermatophore length $(\mathrm{r}=-0.785 ; \mathrm{df}=95 ; \mathrm{P}<0.0001)$ and width $(\mathrm{r}=-0.681$; $\mathrm{df}=95 ; \mathrm{P}<0.0001)$ were negatively correlated with the number of males copulations. Both dimensions were significantly related with the males copulation status (length: $\mathrm{F}=152.91$; $\mathrm{R}^{2}=61.28 \% ; \mathrm{P}<0.0001$ ) (width: $\mathrm{F}=82.07 ; \mathrm{R}^{2}=45.79 \%$; $\mathrm{P}<0.0001$ ) (Fig. 1).

Table II. Fecundity, fertility, longevity (days) and mating duration (min) means $( \pm \mathrm{SE})$ of females paired with Grapholita molesta virgin males and males with distinct mating histories ( $\mathrm{n}=$ number of couples).

\begin{tabular}{lcccc}
\hline Matings & Fecundity & Fertility & Longevity & Mating duration \\
\hline $1^{\circ}(\mathrm{n}=49)$ & $155.8 \pm 8.66 \mathrm{a}^{*}$ & $152.1 \pm 9.00 \mathrm{a}$ & $17.1 \pm 0.92 \mathrm{a}$ & $34.8 \pm 2.62 \mathrm{~b}$ \\
$2^{\circ}(\mathrm{n}=39)$ & $156.6 \pm 8.45 \mathrm{a}$ & $155.6 \pm 8.59 \mathrm{a}$ & $17.0 \pm 1.05 \mathrm{a}$ & $95.1 \pm 14.84 \mathrm{a}$ \\
$3^{\circ}(\mathrm{n}=29)$ & $151.6 \pm 11.82 \mathrm{a}$ & $150.4 \pm 11.72 \mathrm{a}$ & $16.9 \pm 1.10 \mathrm{a}$ & $104.8 \pm 17.90 \mathrm{a}$ \\
$4^{\mathrm{o}}(\mathrm{n}=23)$ & $130.5 \pm 13.75 \mathrm{a}$ & $129.5 \pm 13.90 \mathrm{a}$ & $15.1 \pm 1.26 \mathrm{a}$ & $81.9 \pm 14.26 \mathrm{a}$ \\
\hline$*$ Means values followed by distinct letters in the column differ significantly \\
$(\alpha=0.05)$.
\end{tabular}

Table III. Means $( \pm$ SE) length $(\mathrm{mm})$ and width $(\mathrm{mm})$ of the spermatophores transferred to females by Grapholita molesta virgin males and males with distinct mating histories ( $\mathrm{n}=$ number of couples).

\begin{tabular}{ccc}
\hline Matings & Length & Width \\
\hline $1^{\circ}(\mathrm{n}=37)$ & $1.4 \pm 0.01 \mathrm{a}^{*}$ & $0.8 \pm 0.01 \mathrm{a}$ \\
$2^{\circ}(\mathrm{n}=26)$ & $1.0 \pm 0.02 \mathrm{~b}$ & $0.7 \pm 0.01 \mathrm{~b}$ \\
$3^{\circ}(\mathrm{n}=18)$ & $1.1 \pm 0.03 \mathrm{~b}$ & $0.7 \pm 0.01 \mathrm{~b}$ \\
$4^{\circ}(\mathrm{n}=15)$ & $0.9 \pm 0.01 \mathrm{~b}$ & $0.6 \pm 0.02 \mathrm{~b}$ \\
\hline
\end{tabular}

* Means values followed by distinct letters in the column differ significantly $(\alpha=0.05)$.

The receptivity of $G$. molesta females to recopulation after mating with virgin or mated males, and its effects in fecundity, fertility and longevity. A significantly higher proportion of females $(84 \%)$ was receptive to additional copulations when paired with mated males, compared to those copulated by virgin males $(32.4 \%)\left(\chi^{2}=26.3 ; \mathrm{df}=4 ; \mathrm{P}<0.001\right)$. The majority of females $(67.6 \%)$ that had copulated with virgin males did not copulate again. Among those paired with mated males, $44 \%$ performed three copulations (Fig. 2 ). The refractory period between the first and the second copulation was similar for females initially copulated by virgin $(4.18$ days) or mated males (3.14 days) $(\mathrm{U}=74.5 ; \mathrm{df}=1 ; \mathrm{P}=0.104)$.
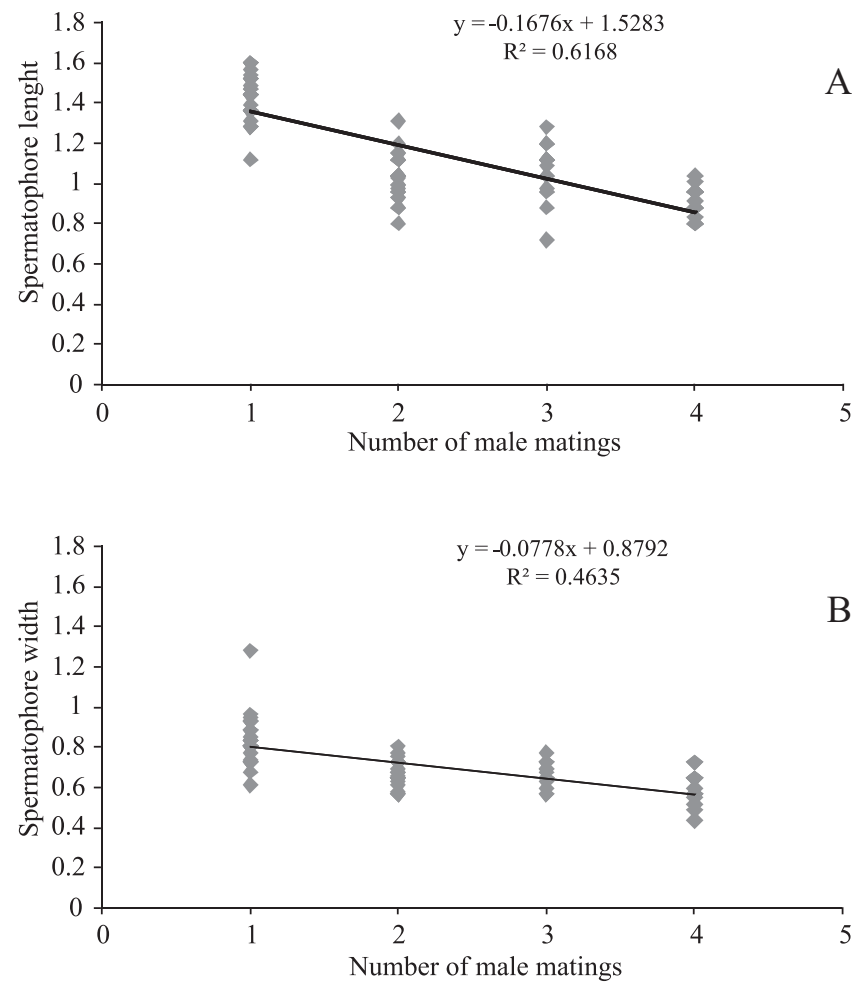

Fig. 1. Spermatophore length (mm) (A) and width ( $\mathrm{mm})(B)$ by number of Grapholita molesta males matings

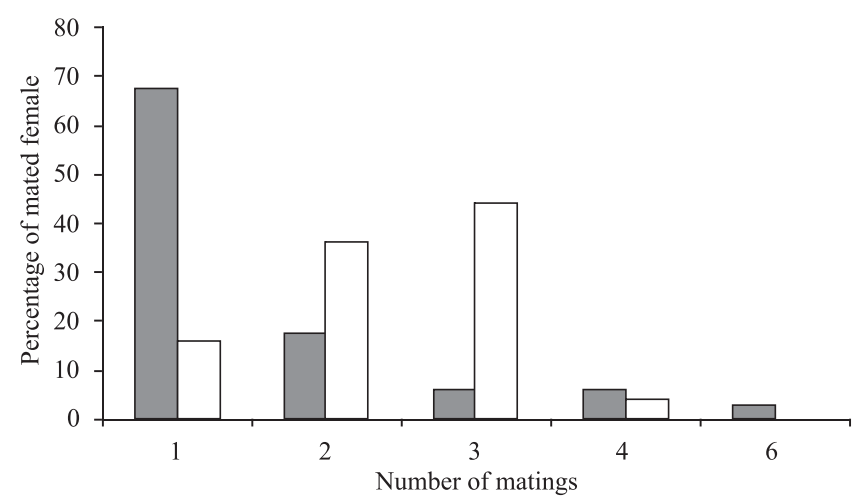

Fig. 2. Percentage of Grapholita molesta females by the number of mating performed through lifetime after mated with virgin (gray bars) or mated males (white bars).

The fecundity $(\mathrm{U}=77 ; \mathrm{df}=1 ; \mathrm{P}=0.068)$, fertility $(\mathrm{U}=79$; $\mathrm{df}=1 ; \mathrm{P}=0.080)$ and longevity $(\mathrm{U}=81 ; \mathrm{df}=1 ; \mathrm{P}=0.094)$ of females that copulated only once were similar to those copulated two or more times (Table IV). The oviposition peak, 
regardless of the number of matings, occurred on the third day after the copulation (Fig. 3). There was no difference in the first mating duration ( $\mathrm{U}=94.5$; $\mathrm{df}=1 ; \mathrm{P}=0.311$ ) between females that mated only once and those that had additional mating.

Table IV. Fecundity, fertility and longevity (days) means ( \pm SE) of Grapholita molesta females that realized one or several matings through lifetime.

\begin{tabular}{lccc}
\hline \multicolumn{1}{c}{ Matings } & Fecundity & Fertility & Longevity \\
\hline One (23) & $174.0 \pm 9.26^{*}$ & $172.2 \pm 9.45$ & $12.30 \pm 1.16$ \\
Several (11) & $216.7 \pm 19.56$ & $214.27 \pm 18.79$ & $14.0 \pm 2.26$ \\
\hline
\end{tabular}

* Means values aren't significantly different $(\alpha=0.05)$.

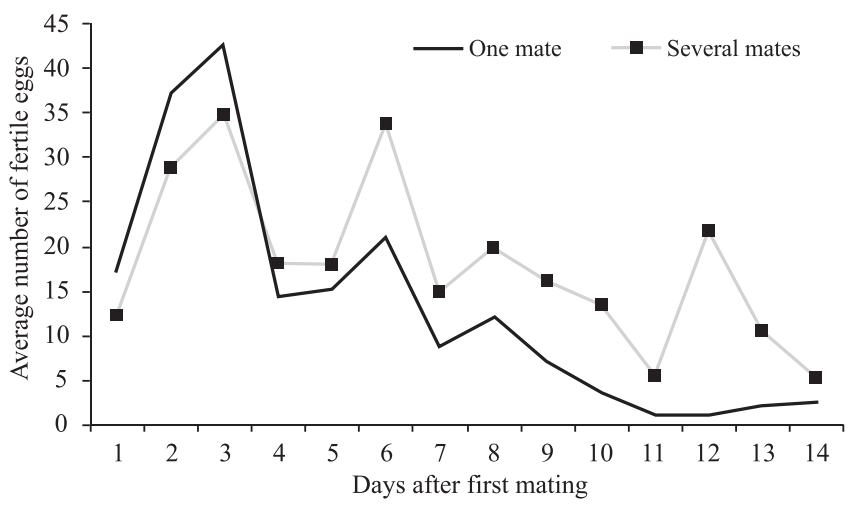

Fig. 3. Average number of fertile eggs of Grapholita molesta females mated with males once or several times through lifetime.

Influence of insect age in the reproductive output. The longest mating duration was recorded for the six, nine and 12 days old insects, compared to the one and three days old ones $(\mathrm{H}=47.74, \mathrm{df}=4, \mathrm{P}<0.05)$ (Table $\mathrm{V})$. The correlation between age and mating duration was significant $(\mathrm{F}=40.45$, $\left.\mathrm{R}^{2}=24.74 \%, \mathrm{P}<0.0001\right)$ (Fig. 4A). The mean fecundity $(\mathrm{H}=34.39, \mathrm{df}=4, \mathrm{P}<0.05)$ and fertility $(\mathrm{H}=44.87, \mathrm{df}=4$, $\mathrm{P}<0.05)$ were significantly higher in the insects of one and three-days-old (Table V). A negative correlation between fertility and age of the insects $(\mathrm{r}=-0.572, \mathrm{df}=119, \mathrm{P}<0.0001)$ was observed. The age was a main factor responsible for female fertility $\left(\mathrm{F}=57.84, \mathrm{R}^{2}=32.14 \%, \mathrm{P}<0.0001\right)$ (Fig. 4B).

Table V. Fecundity, fertility and mating duration $(\mathrm{min})$ means $( \pm \mathrm{SE})$ of Grapholita molesta couples mated at different ages ( $\mathrm{n}=$ number of couples).

\begin{tabular}{cccc}
\hline Ages (day) & Fecundity & Fertility & Mating duration \\
\hline $1(\mathrm{n}=14)$ & $149.0 \pm 14.53 \mathrm{a} *$ & $146.4 \pm 14.50 \mathrm{a}$ & $32.21 \pm 1.92 \mathrm{~b}$ \\
$3(\mathrm{n}=26)$ & $162.1 \pm 8.59 \mathrm{a}$ & $154.9 \pm 8.27 \mathrm{a}$ & $36.07 \pm 1.09 \mathrm{~b}$ \\
$6(\mathrm{n}=32)$ & $107.9 \pm 10.03 \mathrm{~b}$ & $94.4 \pm 9.08 \mathrm{~b}$ & $44.90 \pm 2.45 \mathrm{a}$ \\
$9(\mathrm{n}=26)$ & $96.59 \pm 7.79 \mathrm{~b}$ & $86.62 \pm 7.69 \mathrm{~b}$ & $44.96 \pm 1.53 \mathrm{a}$ \\
$12(\mathrm{n}=22)$ & $78.5 \pm 9.99 \mathrm{~b}$ & $49.5 \pm 11.06 \mathrm{~b}$ & $59.40 \pm 5.38 \mathrm{a}$
\end{tabular}

* Means values followed by distinct letters in the column differ significantly $(\alpha=0.05)$.
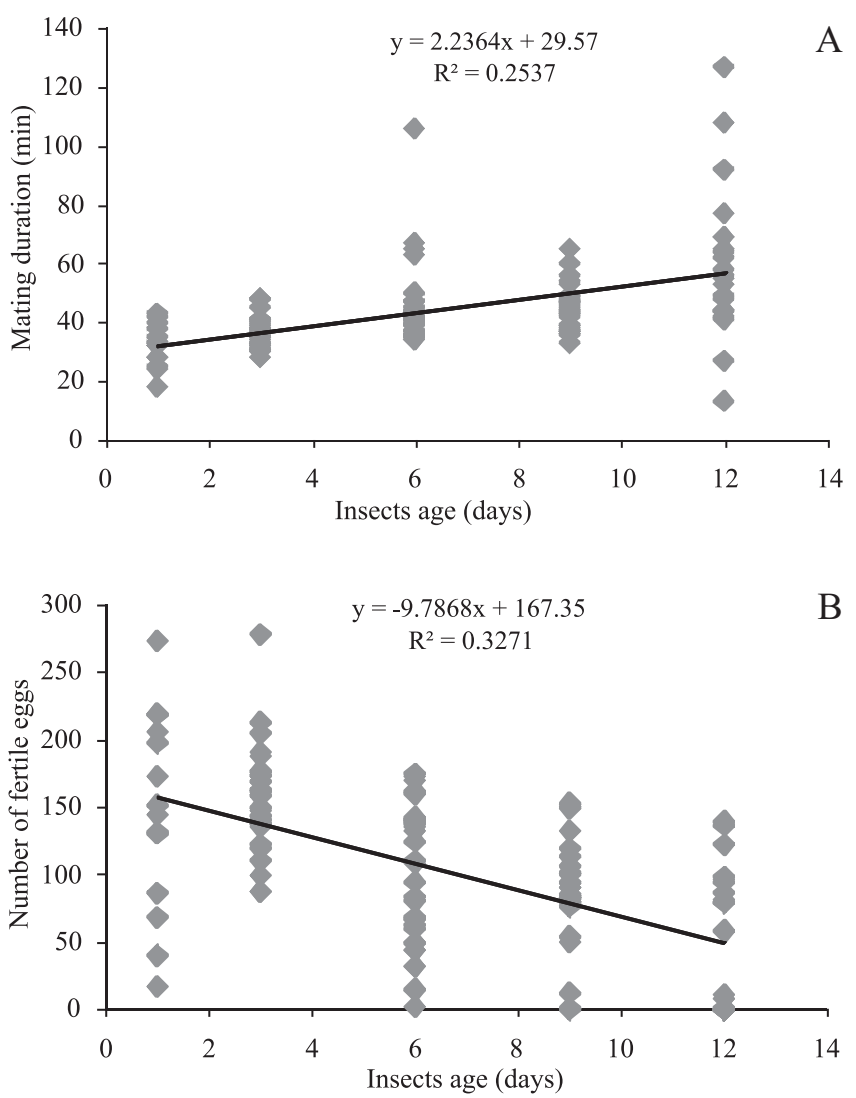

Fig. 4. Mating duration ( $\min$ ) (A) and fertility (B) by the age (in days) of Grapholita molesta individuals.

\section{DISCUSSION}

The mating duration was affected by age and copulation status in G. molesta males. The mating duration mean increased in insects with three or more days old. The longest mating time in late-mating insects may be due to the difficult of males in transferring the sperm with the increase of age, as already recorded in Choristoneura rosaceana (Harris, 1841) (Foster et al. 1995). However, in other tortricids, as Ctenopseutis herana (Felder \& Rogenhofer, 1875), Planotortrix octo Dugdale, 1990 and E. postvittana, the same authors observed that the mating duration was the same from the first to the seventh day of age of the insects.

Grapholita molesta virgin males spend less time mating than those that have already mated. It was also recorded in other lepidopterans species, as C. pomonella (Howell et al. 1978), Choristoneura fumiferana (Clemens, 1865) (Tortricidae) (Marcotte et al. 2005), Pieris rapae (Linnaeus, 1758) (Pieridae) (Bissoondath \& Wiklund 1996) and Jalmenus evagoras (Donovan, 1805) (Lycaenidae) (Hughes et al. 2000). In $C$. pomonella, the time of spermatophore transfer may vary depending on the number of male copulations, i.e., from 37 in the first to $76 \mathrm{~min}$ in the forth (Howell et al. 1978). The authors observed that the copulations that lasted more than 30 minutes generally resulted in bigger spermatophores, while the smallest ones were from those that reached at least 25 minu- 
tes. In G. molesta the spermatophore size and mating time are related to the male mating history, the virgins took less time and transfer bigger spermatophores than the mated ones.

The decrease in the amount of substances, such as proteins, from the male accessory glands, requires a longer interval to produce them in consecutives mating (Oberhauser 1988). In $G$. molesta males, when the second copulation event occurred immediately after the prior, it lasted on average 15 times more than the first, maybe as a consequence of the temporary semen unavailability. According to Wiklund (2003), in lepidopterans, although the males perform subsequent copulations even without the adequate amount of semen, this behavior assures the offspring paternity in a higher number of females.

In $G$. molesta, the spermatophore size was reduced after the first mating, however, it did not affected the number of fertile eggs. The same pattern was observed in Plodia interpunctella (Hubner, 1813) (Pyralidae) (Cook 1999), Cnephasia jactatana Walker, 1863 (Tortricidae) (JiménezPérez \& Wang 2004) and C. pomonella (Knight 2007). The studies indicated that the amount of semen did not affect the reproductive success of these insects. The maintenance of fertility, even when the male deposits less semen, may be related to the enough production quantity of fertile sperm cells to fertilize the females oocytes (Marcotte et al. 2005).

Controversially, in some species, the spermatophore size may directly affect the fertility. In C. jactatana, the spermatophore transferred in the second copulation was $45 \%$ smaller than in the first, decreasing the fertility in about $23 \%$ (Jiménez-Pérez \& Wang 2004). The same was observed in Tuta absoluta (Meyrick, 1917) (Gelechiidae), which had the fertility reduced from 97 to 50\% after mating with virgin and a male that had mated 11 times, respectively (Silva 2008).

The majority of $G$. molesta females paired with virgin males, copulated only once in a lifetime, similar to the observed in E. postvittana (Foster \& Ayres 1996). The remated behavior might related to spermatophore size, the increase in the sperm quantity transfer became female less receptive to further copulations. Even though, smaller spermatophores from multiple mating incurs in a reduction of the amount of substances capable to inhibit the female acceptability to subsequent copulations. However, in other tortricid species, as C. fumiferana and C. rosaceana, the size of the spermatophore received did not affect the female receptivity to remating (Marcotte et al. 2003; Jiménez-Pérez et al. 2003).

The refractory period of once-copulated G. molesta females was the same when paired with virgin and copulated males. The sexual receptivity reestablishment to new mating coincided with the declined of eggs laid, corroborating Marcotte et al. (2006) results with C. rosaceana according to Bissoondath \& Wiklund (1996), short copulations, may also required additional mating. Nevertheless, in this study as well as recorded in C. jactatana (Jimenéz-Pérez et al. 2003), the duration of the first mating was similar in once or multiple-copulated females.

The fecundity, fertility and longevity of Grapholita molesta females that had mated once or more times was the same as observed in Phthorimaea operculella (Zeller, 1873) (Fenemore 1977) and Tecia solanivora (Povolný, 1973) (Gelechiidae) (Rincón \& García 2007). Such results do not corroborate the compiled in some reviews (Arnqvist \& Nilsson 2000; Torres-Vila et al. 2004), in which the authors concluded that, in general, high polyandry levels increase lepidopterans oviposition and fertility.

Multiple mating in G. molesta did not result in the improvement in posture and longevity, it supports the idea that advantage would be more related to sperm selection and genetic variability (Wiklund 2003), than to obtaining nutritional benefits used in oviposition (Vahed 1998). According to Wedell et al. (2002), although the polyandrous behavior is determined by genetic factors, the change in the species polyandry degree may occur as a response to certain needs such as lack of resources.

In the present study fecundity and fertility in $G$. molesta decline when they were paired from the sixth day of life. The decrease may be associated to the delay in the female first copulation, as has been reported in $G$. molesta by Fraser \& Trimble (2001), and in E. postvittana by Foster \& Ayres (1996). According to Chapman (1998), Dytrisia females emerge with all the oocytes they will use throughout life, although posture of infertile eggs occurred before mating might restricted the number of oocytes that would be fertilized in late copulations.

The reproductive performance of $G$. molesta was affected only by the age. The number of males previous mating did not decrease its insemination output, as well as, the females did not depend on additional copulations to achieve the reproductive peak. Such results characterize G. molesta as a species with high reproductive potential, which is an important aspect to assume its pest status in rosaceans orchards.

\section{ACKNOWLEDGEMENTS}

To Conselho Nacional de Desenvolvimento Científico e Tecnológico (CNPq) for the scholarships granted to the first and second authors.

\section{REFERENCES}

Arioli, C. J.; F. Molinari; M. Botton \& M. S. Garcia. 2007. Técnica de criação de Grapholita molesta (Busck, 1916) (Lepidoptera: Tortricidae) em laboratório utilizando dieta artificial para a produção de insetos visando estudos de comportamento e controle. Boletim de Pesquisa e Desenvolvimento: Embrapa Uva e Vinho 13: 1-13.

Arnqvist, G. \& T. Nilsson. 2000. The evolution of polyandry: multiple mating and female fitness in insects. Animal Behaviour 60: 145-164.

Ayres, M.; M. Ayres Jr.; D. L. Ayres \& A. de A. Santos dos Santos. 2005. BioEstat 4.0 Aplicações estatísticas nas áreas da ciências biológicas e médicas. Belém, Sociedade Civil Mamirauá, CNPq, 324 p.

Benz, G. 1969. Influence of mating, insemination, and other factors on oogenesis and oviposition in the moth Zeiraphera diniana. Journal of Insect Physiology 15: 55-71.

Bissoondath, C. J. \& C. Wiklund. 1996. Male butterfly investment in successive ejaculates in relation to mating system. Behavioral ecology and Sociobiology 39: 285-292. 
Chapman, R. F. 1998. The insects: structure and function. Cambridge, Cambridge University Press; 4 ed., 788 p.

Cook, P. A. 1999. Sperm numbers and female fertility in the moth Plodia interpunctella (Hübner) (Lepidoptera; Pyralidae). Journal of Insect Behavior 12: 767-779.

Fenemore, P. G. 1977. Oviposition of potato tuber moth, Phthorimaea operculella Zell. (Lepidoptera: Gelechiidae); fecundity in relation to mated state, age, and pupal weight. New Zealand Journal of Zoology 4: 187-191.

Foster, S. P. 1993. Neural inactivation of sex pheromone production in mated lightbrow apple moths, Epiphyas postvittana (Walker). Journal of Insect Physiology 39: 267-273.

Foster, S. P.; A. J. Howard \& R. H. Ayres. 1995. Age-related changes in reproductive characters of four species of tortricid moths. New Zealand Journal of Zoology 22: 271-280.

Foster, S. P. \& A. J. Howard. 1999. The effects of mating, age at mating, and plant stimuli, on the lifetime fecundity and fertility of the generalist herbivore Epiphyas postvittana. Entomologia Experimentalis et Applicata 91: 287-295.

Foster, S. P. \& R. H. Ayers. 1996. Multiple mating and its effects in the Lightbrown apple moth, Epiphyas postvittana (Walker). Journal of Insect Physiology 42: 657-667.

Fraser, H. W. \& R. M. Trimble. 2001. Effect of delayed mating on reproductive biology of the oriental fruit moth (Lepidoptera: Tortricidae). Canadian Entomologist 133: 219-227.

Gillot, C. 2003. Male accessory gland secretions: Modulators of female reproductive physiology and behavior. Annual Review of Entomology 48: $163-184$.

Howell, J. F.; R. B. Hutt \& W. B. Will. 1978. Codling moth: mating behavior in laboratory. Annals of the Entomological Society of America 71: 891-895.

Hughes, L.; B. S. Chang; D. Wagner \& N. E. Pierce. 2000. Effects of mating history on ejaculate size, fecundity, longevity, and copulation duration in the ant-tended lycaenid butterfly, Jalmenus evagoras. Behavioral ecology and Sociobiology 47: 119-128.

Jiménez-Pérez, A.; Q. Wang \& N. Markwick. 2003. Remating behavior of Cnephasia jactatana Walker females (Lepidoptera: Tortricidae). Journal of Insect Behavior 16: 797-809.

Jiménez-Pérez, A. \& Q. Wang. 2004. Sexual selection in Cnephasia jactatana (Lepidoptera: Tortricidae) in relation to age, virginity, and body size. Annals of the Entomological Society of America 97: 819824.

Karube, F. \& M. Kobayashi. 1999. Presence of eupyrene spermatozoa in vestibulum accelerates oviposition in the silkworm moth, Bombyx mori. Journal of Insect Physiology 45: 947-957.

Knight, A. L. 2007. Multiple mating of male and fmemale codling moth (Lepidoptera: Tortricidae) in apple orchards treated with sex pheromone. Environmental Entomology 36: 157-164.

Kingan, T. G.; P. A. Thomas-Laemont \& A. K. Raina. 1993. Male accessory gland factors elicit change from 'virgin' to 'mated' behaviour in the female corn earworm moth Helicoverpa zea. The Journal of Experimental Biology 183: 61-76.

Marcotte, M.; J. Delisle \& J. N. McNeil. 2003. Pheromonostasis is not directly associated with post-mating sperm dynamics in Choristoneura fumiferana and C. rosaceana females. Journal of Insect Physiology 49: $81-90$

Marcotte, M.; J. Delisle \& J. N. McNeil. 2005. Impact of male mating history on the temporal sperm dynamics of Choristoneura rosaceana and $C$. fumiferana females. Journal of Insect Physiology 51: 537-544.

Marcotte, M.; J. Delisle \& J. N. McNeil. 2006. Impact of male mating history on the postmating resumption of sexual receptivity and lifetime reproductive success in Choristoneura rosaceana females. Physiological Entomology 31: 227-233.

Oberhauser, K. S. 1988. Male monarch butterfly spermatophore mass and mating strategies. Animal Behaviour 36: 1384-1388.

Pinto, A. P.; J. Sant'Ana \& M. Botton. 2005. Influência da idade da fêmea na performance reprodutiva e longevidade de Argyrotaenia sphaleropa (Lepidoptera: Tortricidae). Iheringia 95: 435-440.

Rincón, D. F. \& G. J. García. 2007. Frecuencia de cópula de la polilla guatemalteca de la papa Tecia solanivora (Lepidoptera: Gelechiidae). Revista Colombiana de Entomología 33: 133-140.

Sadek, M. M. 2001. Polyandry in field-collected Spodoptera littoralis moths and laboratory assessment of the effects of male mating history. Entomologia Experimentalis et Applicata 98: 165-172.

Salles, L. A. B. 2001. Mariposa-oriental, Grapholita molesta (Lepidoptera: Tortricidae), p. 42-45. In: E. F. Vilella; R. A. Zucchi \& F. Cantor (eds.). Histórico e impacto das pragas introduzidas no Brasil. Ribeirão Preto, Holos, 173 p.

Silva, S. S. 2008. Fatores da biologia reprodutiva que influenciam o manejo comportamental de Tuta absoluta (Meyrick) (Lepidoptera: Gelechiidae). Dissertação de Mestrado, Recife, Universidade Federal Rural de Pernambuco, 63 p.

Svärd, L. \& J. N. Mcneil. 1994. Female benefit, male risk: polyandry in the true armyworm Pseudaletia unipuncta. Behavioral Ecology and Sociobiology 35: 319-326.

Torres-Vila, L. M.; M. C. Rodríguez-Molina \& J. Stockel. 2002. Delayed mating reduces reproductive output of female European grapevine moth, Lobesia botrana (Lepidoptera: Tortricidae). Bulletin of Entomological Research 92: 241-249.

Torres-Vila, L. M.; M. C. Rodríguez-Molina \& M. D. Jennions. 2004. Polyandry and fecundity in the Lepidoptera: can methodological and conceptual approaches bias outcomes? Behavioral Ecology and Sociobiology 55: 315-324.

Torres-Vila, L. M. \& M. D. Jennions. 2005. Male mating history and female fecundity in the Lepidoptera: do male virgins make better partners? Behavioral Ecology and Sociobiology 57: 318-326.

Vahed, K. 1998. The function of nuptial feeding in insects: a review of empirical studies. Biological Reviews 73: 43-78.

Wedell, N.; C. Wiklund \& P. A. Cook. 2002. Monandry and polyandry as alternative lifestyles in a butterfly. Behavioral Ecology 13: 450-455.

Wedell, N. 2003. Sperm competition in butterflies and moths, p. 49-81. In: M. D. E. Fellowes; G. J. Holloway \& J. Rolff, (eds.). Insect Evolutionary Ecology - Proceedings of the Royal Entomological Society's 22nd Symposium. Cambridge, CABI Publishing, 539 p.

Wiklund, C. 2003. Sexual selection and evolution of butterfly mating systems, p. 67-90. In: C. L.; Boggs, W. B. Watt \& P. R. Ehrlich. 2003. Butterflies: ecology and evolution taking flight. Chicago, University of Chicago Press, $x v+739$ p.

Received 8/10/2010; accepted 10/7/2012

Editor: Paulo Roberto Valle da Silva Pereira 